\title{
Student Readiness in Learning Arabic Language based on Blended Learning
}

\author{
Norasyikin Osman (Corresponding author) \\ Pusat Pengajian Bahasa Arab, Fakulti Bahasa dan Komunikasi, Universiti Sultan Zainal Abidin, Kampus Gong Badak, 21300, Kuala Terengganu, \\ Terengganu, Malaysia \\ E-mail: norasyikinosman@unisza.edu.my \\ Mohd Isa Hamzah \\ Jabatan Pendidikan dan Kesejahteraan Komuniti, Fakulti Pendidikan, Universiti Kebangsaan Malaysia, 43600 UKM Bangi, Selangor, Malaysia
}

Received: 19-02-2017

Published: 01-09-2017
Accepted: 16-04-2017

doi:10.7575/aiac.ijalel.v.6n.5p.83
Advance Access Published: July 2017

URL: http://dx.doi.org/10.7575/aiac.ijalel.v.6n.5p.83

\begin{abstract}
Learning with technology or e-learning has been taking place in all areas of education including in learning and teaching of Arabic language. Despite the widespread use of e-learning for Arabic language, in line with the current technological advancements, the role of face-to-face classroom interactions must not be neglected. Face-to-face learning and e-learning have their own strengths. Hence, a combination of both elements in teaching and learning as afforded by blended learning may be an excellent choice. This study seeks to identify student readiness in learning Arabic language based on blended learning approach among students at university level. The research took place at University Sultan Zainal Abidin (UniSZA), Malaysia involving 248 students. The students were asked to answer the distributed questionnaires. The questionnaires used 1-5 points Likert scale which are strongly not agree, not agree, not sure, agree and strongly agree. The need analysis encompassed the presence of facilities supporting blended learning, the internet and e-learning literacy among students and their readiness to adopt blended learning. The findings highlight the important roles played by both the students and the institution in providing facilities needed to support blended learning. The findings also reported that the existing facilities are in a state of readiness for the implementation of blended learning. The institution provides wireless connection throughout the campus while $96 \%$ of the students own a laptop. In addition, students are also discovered to be internet-savvy besides displaying readiness to adopt blended learning. Further studies are recommended in exploring how to design and develop successful blended learning in teaching and learning Arabic language.
\end{abstract}

Keywords: Blended learning, e-learning, face to face, readiness

\section{Introduction}

For decades, e-learning has formed its niche in the national education system in parallel with the rapid development in technology. The use of technology in classroom teaching and learning has become an important aspect as evident through the implementation of the Malaysia Education Blueprint (Higher Education) 2015-2025 launched by the Prime Minister in April 2015. Among the 10 shifts introduced in the plan, globalised online learning is one of the aspirations to be attained. A blended learning model is expected to be a vital pedagogical approach in all higher learning institutions and consequently, strengthening the role played by e-learning. Nevertheless, face-to-face classroom interactions remain relevant because not all elements of teaching and learning can be conveyed solely through technology. For instance, according to Nur Syamimi and Norrafandy (2010), personal, interpersonal, communication and leadership skills cannot be taught through e-learning. Tayebinik and Puteh (2013) further reiterated that face-to-face learning is irreplaceable because of the presence of body gestures, voice intonations, facial expressions and eye contact which all contribute to teaching and learning processes. Nevertheless, blended learning is considered significant due to the integration of both e-learning and face-to-face interactions (Inoue, 2010).University Sultan Zainal Abidin (UniSZA) is a new institution in the process of implementing a blended learning approach. Thus, need analysis has been conducted in this study to investigate the facilities provided and students' readiness towards implementation of blended learning in learning Arabic language.

\section{Background study}

There are various definitions of blended learning. The three definitions that are commonly discussed are:

i. a combination of face-to-face and online teaching,

ii. a combination of technologies

iii. a combination of methodologies (Sharma (2010); Oliver, \& Trigwell (2005); Graham, Allen, \& Ure (2003). 
However the combination of face-to-face and e-learning is the definition most widely used (Graham 2003; Thorne 2003 ;Sharma \& Barrett 2007; Bliuc, Goodyear \& Ellis 2007).

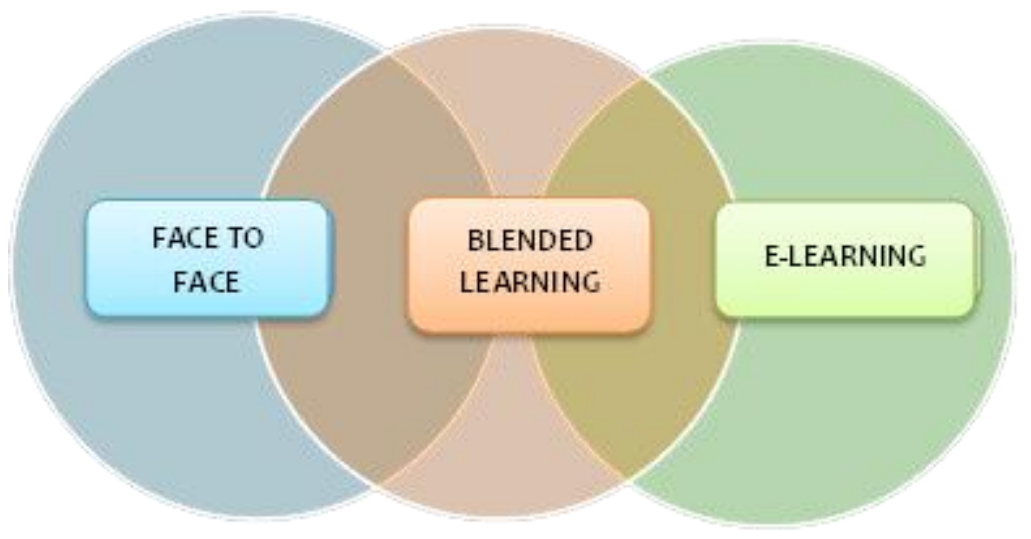

Figure 1. Blended learning illustration

Figure 1 illustrates the definition of blended learning which is a combination of face to face and e-learning. The strengths and advantages of face to face and e-learning are the main features of blended learning.

"Those who use blended approaches base their pedagogy on the assumption that there are inherent benefits in face-toface interaction (both among learners and between learner and instructor) as well as the understanding that there are some inherent advantages to using online methods in their teaching. Thus the aim of those using blended learning approaches is to find a harmonious balance between online access to knowledge and face-to-face human interaction."

(Osguthorpe and Graham, 2003, p:228)

Some factors have been identified in the implementation blended learning. The factors include pedagogical richness, access to knowledge, social interaction, personel agency, cost-effectiveness and ease of revision (Osguthorpe \& Graham, 2003). Out of these factors, the main ones are (1) improved pedagogy, (2) increased access and flexibility and (3) increased cost-effectiveness, as explained by Graham, Allen and Ure (2003, 2005).

Blended learning has its own merits in upgrading the teaching and learning in higher institutions. Graham (2006) discussed some factors contributing to the implementation of blended learning such as improving pedagogy, upgrading accessibility and flexibility, as well as increasing cost effectiveness.

FarahizaZaihanAzizan (2010) listed down the advantages of blended learning which contribute to the improvement in social communications, the betterment of students' self-confidence and abilities, enhancing the quality of the learning environment and developing critical thinking while promoting integration of technology as an effective tool to convey information to students. Izudin Syarif (2013) reported that there is a significant improvement in the motivation and performance of students following blended learning compared to those who underwent only face-face-to-face learning. Norasyikin (2014) also concluded that the element of physical and virtual meetings between lecturers and students have great bearing in the learning of a second language.

There are numerous studies on the teaching of Arabic language using technology with most findings indicating positive feedback. For instance, a study by Rafidah and MohdHamdi (2013) supported the view that technology-based teaching and learning contributes to students being more prepared and active in learning Arabic. Similar findings were also reported in studies by Muhammad Haron et al. (2010), Norhayati et al. (2013) and KhairulNizam et al. (2014). Nevertheless, face-to-face learning is still preferred by teachers and lecturers due to lack of skills, interests and facilities for expansive use of technology in the teaching and learning of Arabic (Zawawi, 2008; Lubna, Seewen \& Wan Azura, 2008; Ayyad, Basha \& Ahmad, 2011).

Hence, blended learning is seen as a middle point which connects technology-based pedagogy and the traditional faceto-face learning. Marsh (2012) also stated that blended learning, which was first conceived around the year 2000, is meant to support the traditional learning method.

In 2012, University Sultan Zainal Abidin (UniSZA) published a policy on e-learning which stipulated that every lecturer incorporate blended learning instructions. However, the students' readiness to follow such approach remained unexplored. Accordingly, this study aims to investigate the extent of students' readiness as well as facilities available in the implementation of pedagogical instructions based on blended learning. Previous researches on learner perceptions towards blended learning have revealed preferences for face-to-face learning in addition to application of technology. Furthermore, students also responded that blended learning could improve the process of learning (Akkoyunlu \& Soylu, 2008; Seesink, 2007). 


\section{Research objectives}

This study is initiated in response to the teaching and learning trend based on blended learning with the objectives being:-

(1) to investigate the facilities available to support the implementation of blended learning approach.

(2) to identify the internet usage and e-learning literacy among students.

(3) to identify students' readiness in learning Arabic based on blended learning approach.

\section{Methodology}

This is a descriptive study which will describe facilities available and students' readiness towards blended learning. This is a quantitative-based study with data collected from questionnaires modified from previous studies. A pilot test was carried out before they were used in the actual study. The questionnaires contained demographic details as well as information relating to need analysis in terms of facilities provided, internet usage and e-learning literacy and students' readiness to undergo Arabic lessons based on blended learning. A close question format involving yes-or-no answer was used for constructs on facilities and internet and e-learning literacy. On the other hand, constructs on student readiness for blended learning used a five-point Likert scale ranging from strongly disagree, disagree, not sure, agree and strongly agree.

A random selection of respondents was carried out involving 248 First Year undergraduates pursuing basic National Arabic Language, a course specially prepared for those with no basic Arabic at UniSZA. The total number of undergraduates taking up the course was 384 , thus, a sample of 248 respondents for the study is considered to have fulfilled the sampling requirement proposed by Krejcie and Morgan (1970).

Upon completion, the questionnaires were then analysed using the Statistical Package for the Social Sciences (SPSS). For the section on facility readiness in implementing blended learning, a descriptive analysis was obtained by calculating the percentage. While for internet usage and e-learning literacy, mean scores were used to determine student readiness in following blended learning approach.

\section{Findings}

Table 1 displays the respondent distribution by gender with 61 males and 187 females were involved in the study.

Table 1. Respondent demographics by gender

\begin{tabular}{ccc}
\hline Gender & Total & Percentage \\
\hline Male & 61 & 24.6 \\
Female & 187 & 75.4 \\
\hline Total & 248 & 100 \\
\hline
\end{tabular}

Table 2. Availability of facilities

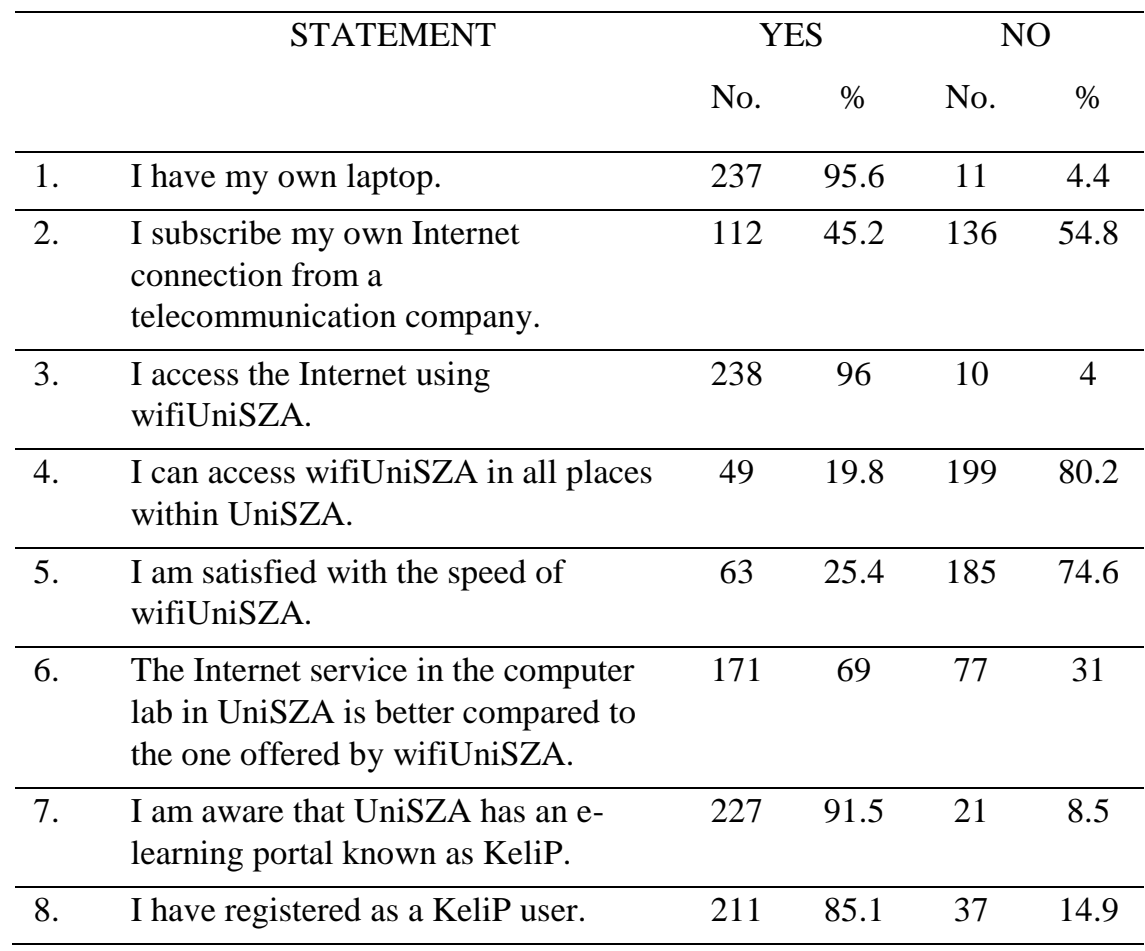


Table 2 displays the facilities owned by and provided to students by UniSZA in encouraging the implementation of blended learning. From the table, $95.6 \%$ of the respondents have their own laptops and $96 \%$ of them accessed the internet using the wireless connection provided by UniSZA. Nevertheless, internet access is not available at all places within UniSZA, as claimed by $80.2 \%$ of the respondents. Furthermore only $25.4 \%$ respondents were satisfied with the speed of the connection available to them. Regarding the internet connection, $45.2 \%$ of the respondents subscribed to a paid internet connection. When it comes to e-learning portal named KeLiP by UniSZA, 91.5\% respondents were aware of its existence and $85.1 \%$ of them are registered users.

Table 3. Internet usage and e-Learning literacy

\begin{tabular}{llcccc}
\hline \multicolumn{1}{c}{ STATEMENT } & Nol & $\%$ & No & $\%$ \\
\hline No & \multicolumn{1}{c}{ YES } & \multicolumn{2}{c}{ NO } \\
\hline 1 & $\begin{array}{l}\text { I have experienced e- } \\
\text { learning. }\end{array}$ & 112 & 45.2 & 136 & 54.8 \\
\hline 2 & $\begin{array}{l}\text { I always search for } \\
\text { information using the }\end{array}$ & 208 & 83.9 & 40 & 16.1 \\
$\quad \begin{array}{l}\text { Internet. } \\
\text { I often use the email. }\end{array}$ & 110 & 44.4 & 138 & 55.6 \\
\hline 4 & $\begin{array}{l}\text { I am familiar chatting } \\
\text { online. }\end{array}$ & 124 & 50.0 & 124 & 50.0 \\
\hline 5 & $\begin{array}{l}\text { I am familiar with } \\
\text { downloading files. }\end{array}$ & 182 & 73.4 & 66 & 26.6 \\
\hline 6 & $\begin{array}{l}\text { I am familiar watching } \\
\text { videos on websites. }\end{array}$ & 197 & 79.4 & 51 & 20.6 \\
\hline 7 & I have typed in Arabic. & 101 & 40.7 & 147 & 59.3 \\
\hline 8 & $\begin{array}{l}\text { I have surfed websites in } \\
\text { Arabic. }\end{array}$ & 88 & 35.5 & 160 & 64.5 \\
\cline { 2 - 6 } & & & & & \\
\hline
\end{tabular}

Based on Table 3, item 2 records the highest percentage with $83.9 \%$ respondents claimed to have used the internet for information searching while $79.4 \%$ respondents stated that they are familiar with watching videos on websites. In regard to downloading files from the internet, $73.4 \%$ respondents had done so. These three aspects are indicators of the students' familiarity with internet usage in their daily lives. For the remaining items on the usage of internet for learning, low percentages were recorded. For instance, for item 1, only $45.2 \%$ respondents claimed to have experienced learning online while only $44.4 \%$ stated that they often use the email. The two items on the use of internet for learning Arabic recorded $40.7 \%$ and $35.5 \%$ respectively.

Table 4. Student readiness in adopting blended learning

\begin{tabular}{llc}
\hline & STATEMENT & Mean \\
\hline 1 & I am capable of learning on my own. & 2.40 \\
\hline 2 & I am self-reliant in completing given task. & 3.33 \\
\hline 3 & $\begin{array}{l}\text { I am comfortable in using technology in } \\
\text { learning. }\end{array}$ & 3.85 \\
\hline 4 & I have skills to apply e-learning. & 3.44 \\
\hline 5 & $\begin{array}{l}\text { I am confident face-to-face learning must not } \\
\text { be neglected as it has its own advantages. }\end{array}$ & 4.34 \\
\hline 6 & $\begin{array}{l}\text { I believe e-learning has its own strength and } \\
\text { weakness. }\end{array}$ & 3.07 \\
\hline 7 & $\begin{array}{l}\text { I am more interested to follow blended } \\
\text { learning (a combination of face-to-face and } \\
\text { e-learning) compared to face-to-face learning } \\
\text { alone. }\end{array}$ & 3.59 \\
\hline 8 & $\begin{array}{l}\text { I am more interested to follow blended } \\
\text { learning compared to e-learning fully. }\end{array}$ & 3.32 \\
\hline 9 & $\begin{array}{l}\text { I am ready to follow blended learning } \\
\text { anytime. }\end{array}$ & 3.69 \\
\hline 10 & $\begin{array}{l}\text { I am ready to face challenges in following } \\
\text { blended learning. }\end{array}$ \\
\hline
\end{tabular}


Based on Table 4, the highest mean score was recorded by the statement related to the importance of face-to-face learning (m - 4.34) and thus, indicating students' preference for face-to-face learning. Nevertheless, the students do admit to knowing of the advantages and disadvantages of e-learning as translated by the mean score for the statement on e-learning having its own strength and weakness ( $\mathrm{m}$ - 4.07). For the idea of students being comfortable using technology in learning, the mean score recorded was 3.85. The role of e-learning is also recognised by the students and this is evident from a relatively high mean score ( $\mathrm{m}$ - 3.69) for the statement on students' readiness to follow blended learning anytime. In regard to interest in blended learning, it obtained 3.59 which is considered moderately high..

\section{Discussion}

The study involved 248 undergraduates selected randomly from a population of 384 students with 187 male and 61 female respondents. The facilities provided played important roles in supporting the implementation of blended learning and it has been revealed that almost all students surveyed have laptops (95.6\%) which to an extent reflects high level of readiness for the use of computer in learning. Almost half of the respondents are also subscribers to paid internet line from telecommunication companies. On the part of the institution, UniSZA also provides wireless connection with 96\% of the respondents claiming to have used the service. The same goes with the learning portal developed by UniSZA called KeLiP which is highly recognised by the students (91.5\%), of whom, a majority have registered as users of that learning portal $(85.1 \%)$. These findings reflect readiness on both the students and the institution in the implementation of blended learning. Nevertheless, UniSZA still needs to upgrade its internet service as $74.6 \%$ students raised dissatisfaction about the service provided since access to the internet is not available in all areas within the campus. The same result was also reported by Aliza Adnan et al. (2013) in their study where internet problem is one of the main issues in implementing e-learning.

On constructs relating to internet usage and e-learning literacy, the use of internet for information obtained the highest percentage (83.9\%), and hence, indicating the students' exposure to and familiarity with the internet. Similar findings were also reported by Ahmad Johari and Norbaizura (2011) and Muhammad Sukri et al. (2007). Watching videos on websites is also another familiarity among the students (79.4\%) followed by downloading files (73.4\%). All of these show that the students are experienced users of the internet and such results were also found in a study by Khoirunnisak et al. (2015) which revealed that there is a high readiness level among students for web-based learning. Nevertheless, in this study, a low percentage was recorded for students' involvement in web-based learning as not even half of the students went through the experience which is probably due to lack of exposure in e-learning since the students are still in their first year. Low percentages were also obtained in the use of computer for typing in Arabic and surfing Arabic websites since this course was prepared for those without prior knowledge of the Arabic language.

The study identified the students' readiness in following blended learning using a set of questions on a five-point scale ranging from strongly disagree, disagree, not sure, agree and strongly agree. The mean score was used for measuring student readiness with interpretation of means based on Table 5 .

Table 5. Interpretation of score and level

\begin{tabular}{cc}
\hline Score & Level \\
\hline $1.00-2.33$ & Low \\
$2.34-3.66$ & Moderate \\
$3.67-5.00$ & High \\
\hline
\end{tabular}

Source: Majid Konting, 1990

Out of the 10 constructs, the highest mean score was recorded by the statement on the importance of face-to-face learning $(\mathrm{m}-4.34)$ followed by the strengths and weaknesses of e-learning $(\mathrm{m}-4.07)$. The students also reported of being comfortable using technology in their learning $(m-3.85)$ and being ready for blended learning (mean - 3.69). The findings from the four statements are good indicators of the students' high level of readiness for both face-to-face learning as well as e-learning. The findings are also supported by Usta and Özdemir (2007) who stated that students have positive perceptions towards blended learning. Nevertheless in this study, the item on self-learning recorded the lowest mean score (mean - 2.40) which reflects that the students may not be fully ready to learn on their own as they are still dependent on guidance from the lecturers. Furthermore, other researchers such as Tayebinik and Puteh (2012), Chun and Lee (2013) and Nurul Nadirah and Fariza (2016) have recorded that students have positive attitudes towards implementation of blended learning. Garrison Kanuka (2004), Rhema and Miliszewska (2014) and Vaughan (2007) also reported similar findings which indicated that students are interested in pursuing a blended learning based learning.

\section{Conclusion}

In order to enhance awareness on blended learning, continuous efforts should be carried out and this study has taken the first step in identifying the students' readiness. It has been discovered that a majority of students display a high level of readiness in accepting blended learning and with well-equipped facilities on campus, the implementation of such learning approach will be made easier. Future research might explore the implementation methods, taking into account the students, lecturers, courses and the institutions themselves. It is hoped that blended learning can revolutionise and further upgrade the quality of the national education system. 


\section{References}

Johari Sihes, A. \& Norbaizura, S. (2011). "Pelaksanaan Perlaksanaan E-Pembelajaran Di Kalangan Pelajar Fakulti Pendidikan Dan Fakulti Kejuruteraan Mekanikal Universiti Teknologi Malaysia Skudai”, Journal of Technical, Vocational \& Engineering Educational, 3, 33-51.

Akkoyunlu, B., \& Yilmaz-Soylu, M. (2008). “A Study of Student's Perceptions in a Blended Learning Environment Based on Different Learning Styles”, Educational Technology \& Society, 11(1), 183-193.

Aliza, A., Rosseni, D., Mohd Shaferi, M.H., Haslina, H. , Junaida, A., Norijah, M. \& Md Norzamani, A. H. (2013). "Cabaran dalam Pelaksanaan E-Pembelajaran bagi Program Pensiswazahan Guru (PPG)", Jurnal Penyelidikan Tempawan, pp. 13-23.

Ayyad Abdullah, Basha Abu Bakar, Ahmad Baghdawan. (2011). "Ta'lim wa taallum allughotul arabiah fi malizia baina attahdiyyat wa attomuh" Prosiding Seminar Antarabangsa Pengajaran Bahasa Arab 2011 (SAPBA'11): Wawasan dan Cabaran Malaysia-China.

Bliuc, A. M., Goodyear, P., \& Ellis, R. A. (2007). "Research focus and methodological choices in studies into students' experiences of blended learning in higher education”, The Internet and Higher Education vol.10 No.4, pp. 231-244.

Chun Meng, T., \& Lee Yen, Ch. (2013). Readiness for Blended Learning: Understanding Attitude of University Students. International Journal of Cyber Society and Education 6(2), 79-100.

Farahiza Zaihan, A. (2010). "Blended learning in higher education institution in Malaysia", in Proceedings of Regional Conference on Knowledge Integration in ICT, pp. 454-466.

Garrison, D. R., \& Kanuka, H. (2004). Blended learning: Uncovering its transformative potential in higher education. The internet and higher education, 7(2), 95-105.

Graham, C. R. (2003). "Blended learning systems", in CJ Bonk \& CR Graham, The handbook of blended learning: Global perspectives, local designs. Pfeiffer.

Graham, C. R., Allen, S., Ure, D., (2003), Blended learning environments. A review of the research literature. Unpublished manuscript, Brigham Young University.

Inoue, Y. (2010), "Reflections :Two Years after Implementing a Blended Educational Research Course. Cases on Online and Blended Learning Technologies in Higher Education : Concepts and Practices EBSCO Publishing, pp. 145165.

Izudin, S. (2013), "Pengaruh Model Blended Learning terhadap Motivasi Dan Prestasi Belajar Siswa SMK" Jurnal Pendidikan Vokasi, 2(2), pp.234-249.

Jamil, A. (2002), Pemupukan budaya penyelidikan di kalangan guru di sekolah: Satu penilaian. Tesis Dr. Fal. Universiti Kebangsaan Malaysia, Bangi.

Khairul Nizam Mohd, K., Nik Mohd Rahimi, N.Y., Nurul Hana Ab, N. (2014), "Persepsi Pelajar Diploma Pelancongan Politeknik Ibrahim Sultan Terhadap Pengajian Bahasa Arab Komunikasi (AA 303) Melalui "You Tube", International Journal of Islamic Studies and Arabic Language Education, 1(1), pp 26-34.

Khoirun Nisak Mat Saad, Norasyikin Osman, Kamarul Shukri Mohd Teh \& Siti Salwa Mohd Noor. (2015). "Penggunaan Kelip Dalam Pembelajaran Bahasa Arab: Suatu Tinjauan Di Universiti Sultan Zainal Abidin", The Online Journal of Islamic Education July, 3(2).

Krejcie, R.V. \& Morgan, D.W. (1970), "Determining sample size for research", Educational and Psychological Measurements, 30, 607-610.

Lubna Abd, R., Seewen Ali, I. \& Wan Azura Wan, A. (2008), "Halangan dalam penggunaan peralatan teknologi dalam pengajaran bahasa Arab kepada penutur bukan jati: kajian di USIM, UIAM dan UKM". Laporan penyelidikan USIM $\operatorname{PPPP}(K) / 2007$

Marsh, D. (2012). Blended Learning Creating Learning Opportunities for Language Learners, Cambridge University Press, New York.

Mohd Majid, K. (2000). Kaedah Penyelidikan Pendidikan. Dewan Bahasa dan Pustaka. Kuala Lumpur.

Muhammad Haron Husaini, Mohamad Rofian Ismail, Mohammad Imran Ahmad, Ghazali Zainuddin, Normah. (2010), Persepsi pelajar terhadap pengintegrasian kemahiran bahasa arab dengan multimedia. Proceedings of Regional Conference on Knowledge Integration in ICT, hlm. 750.

Muhammad Sukri, S., Mohd Anuar Abdul, R., \& Ting Kungm Sh. (2007), "Kajian Mengenai Penggunaan EPembelajaran (E-Learning) Di Kalangan Pelajar Jurusan Pendidikan Teknikal Dan Vokasional Di Institusi Pengajian Tinggi (IPTA) Negeri Johor", 1st International Malaysian Educational Technology Convention, pp. 1123-1128.

Norasyikin, O., Kamarul Zaman Abd, G. \& Mohd Isa, H. (2014). "Blended learning dalam pembelajaran Bahasa", 4th International Conference and Exhibition on Islamic Education 2014 (ICIED 2014) Kelantan, Malaysia. pp. $1249-1253$.

Norhayati Ch.H., Shaferul Hafes, S., Mohd Fauzi Abdul, H. (2013), "Persepsi Pelajar Terhadap Penggunaan Animasi dalam Pembelajaran Bahasa Arab", Jurnal Teknologi, 63(1). 
Nurul Nadirah Binti Mohd, K. \& Fariza, K. (2016). Kesesuaian kaedah pembelajaran teradun dari sudut pandangan pelajar pascasiswazah. Proceedings of Cross-Cultural Education for Sustainable Regional. hlm. 638-648.

Nur Syamimi Mohd, R. \& Norrafandy, Y. (2010). Blended learning: Overcome the weaknesses of e-learning and traditional approach. edupress 2010, available at: https://core.ac.uk/download/files/392/11790054.pdf (accessed 20 November 2015)

Oliver, M., \& Trigwell, K. (2005), “Can 'Blended Learning'Be Redeemed?”, E-learning and Digital Media, vol. 2, no.1, pp. 17-26.

Osguthorpe, R. T., \& Graham, C. R. (2003), "Blended Learning Environments: Definitions and Directions", Quarterly Review of Distance Education, 4(3), pp. 227-33.

Rafidah, J. \& Mohd Hamdi, Y. (2013), "Keberkesanan Pengajaran dan Pembelajaran Bahasa Arab Berbantukan multimedia: Satu kajian di Politeknik Ibrahim Sultan", Persidangan pendidikan (Penyelidikan dan Inovasi) Dalam Pendidikan dan Latihan Teknikal dan Vokasional (CiE-TVET 2013).

Rhema, A., \& Miliszewska, I. (2014). Analysis of student attitudes towards e-learning: The case of engineering students in Libya. Issues in informing science and information Technology, 11, 169-190.

Seesink, M. T. (2007), Using blended instruction to teach academic vocabulary collocations: A case study. Unpublished PhD thesis, West Virginia University, USA.

Sharma, P. (2010), “Blended learning”, ELT journal, 64(4), pp.456-458.

Sharma, P., \& Barrett, B. (2007). Blended learning: Using technology in and beyond the language classroom. Oxford: Macmillan.

Tayebinik, M., \& Puteh, M. (2012), Blended Learning or E-learning, available at: http://arxiv.org/ftp/arxiv/papers/1306/1306.4085.pdf. (accessed 20 November 2015)

Thorne, K. (2003), Blended Learning: How to Integrate Online and Traditional Learning. Kogan Page Limited, London.

Usta, E., \& Ozdemir, S. M. (2007). An Analysis of Students' Opinions about Blended Learning Environment. Online Submission.

Vaughan, N. (2007). Perspectives on blended learning in higher education. International Journal on ELearning, 6(1), 81.

Zawawi, I. (2008). Penilaian pelaksanaan kurikulum kemahiran bertutur bahasa Arab komunikasi di Sekolah Menengah Kebangsaan Agama. Tesis Dr. Falsafah, Universiti Kebangsaan Malaysia, Bangi. 